\title{
IMPLEMENTASI ADIWIYATA DALAM UPAYA MEWUJUDKAN PENDIDIKAN LINGKUNGAN HIDUP DI SD NAHDLATUL ULAMA JALAN PUKAT NO. 1 KOTA MEDAN
}

\author{
SAID MUZAMBIQ*
}

\begin{abstract}
This research used a descriptive qualitative approach. The aims are to describe the implementation Adiwiyata, describe a supporting factor, describes inhibiting factors, and provide a description in overcoming obstacles adiwiyata program at NU SD trawl Road No. 1 Medan. The results showed that the policy environment in the school is going well and integrated into each subject's work utilization of waste paper, palastic and aqua bottles to decorate the atmosphere of the school environment. Besides the establishment of cooperation from local government agencies through the socialization of key activities with the approach of the students and educators in order to gain a good knowledge of the environment, so as to create an atmosphere and environmentally friendly school environment cultured. This proved to won your school's national champion. Some of the barriers are still found among others the limited landfill infrastructure, security officers and public participation around the related concepts of environmentally schools, funding issues, and the support of the community and other agencies are still low. Schools have taken steps to overcome obstacles in the form of strategies to be intensified cooperation with various parties, governments and local communities.
\end{abstract}

Keywords: adiwiyata, environment

\section{PENDAHULUAN}

Adiwiyata

pengertian atau makna adalah sebagai tempat yang baik dan ideal

\footnotetext{
* Staf Pengajar Jurusan Teknik Geologi Institut Teknologi Medan
}

dimana dapat diperoleh segala ilmu pengetahuan dan berbagai norma serta etika yang dapat menjadi dasar manusia menuju terciptanya kesejahteraan huidup kita dan menuju cita-cita pembangunan 
berkelanjutan.

Adiwiyata

dicanangkan untuk mendorong dan membentuk sekolah-sekolah di Indonesia agar dapat turut melaksanakan upaya pemerintah menuju pelestarian lingkungan dan pembangunan berkelanjutan bagi kepentingan generasi sekarang maupun yang akan datang.. Menyikapi hal tersebut, Kementerian Negara Lingkungan Hidup pada tahun 2006 mencanangkan Program Adiwiyata sebagai tindak lanjut dari MoU pada tanggal 3 Juni 2005 antara Menteri Negara Lingkungan Hidup dan Menteri Pendidikan Nasional. Program Adiwiyata sendiri baru mulai tahun 2006 ini dilaksanakan dan dikhususkan untuk Pulau Jawa, karena Kementerian Lingkungan Hidup masih mencari model untuk kriterianya. Tetapi sejak tahun 2007 program ini kemudian dilaksanakan menyeluruh ke tiap provinsi yang ada di Indonesia (KLH, 2010).

Berdasarakan hal tersebut penulis mencoba melakukan pendiskripsian peninjauan langsung sejauhmana Adiwiyata tersebut berlangsung dengan lokasi sekolah SD Nahdlatul Ulama Medan.

Secara umum tujuan program Adiwiyata adalah untuk mengetahui : (1) gambaran kondisi lingkungan pendidikan sebelum adanya program Sekolah Peduli dan Berbudaya Lingkungan (SPBL) (2) program Kurikulum lingkungan di masyarakat pendidikan efektifitas program Sekolah Peduli dan Berbudaya Lingkungan (SPBL) (4) apa saja kendala dan usaha dalam mengatasi pelaksanaan program Sekolah Peduli dan Berbudaya Lingkungan (SPBL).

Penelitian ini merupakan penelitian deskriptif kualitatif. Teknik pengumpulan data yang digunakan adalah wawancara observasi dan dokumentasi. Teknik analisis data yang digunakan adalah model analisis deskriptif. Penelitian dilakukan di SD Nahdlatul Ulama Medan dengan objek penelitian adalah efektivitas pelaksanaan program adiwiyata (sekolah peduli dan berbudaya lingkungan).

Menurut Widaningsih (2010) secara formal pendidikan lingkungan hidup menjadi salah satu alternatif yang rasional untuk memasukkan pendidikan lingkungan ke dalam kurikulum.Pendidikan lingkungan hidup merupakan salah satu faktor penting dalam keberhasilan dalam pengelolaan lingkungan hidup dan juga menjadi sarana yang sangat penting dalam menghasilkan sumber daya manusia yang dapat 
melaksanakan prinsip pembangunan berkelanjutan.

Nurjhani dan Widodo (2009), menjelaskan bahwa pendidikan lingkungan dibutuhkan dan harus diberikan kepada anak sejak dini agar mereka mengerti dan tidak merusak lingkungan. Hal ini dipengaruhi beberapa aspek antara lain:

1. Aspek kognitif, pendidikan lingkungan hidup mempunyai fungsi untuk meningkatkan pemahaman terhadap permasalahan lingkungan, juga mampu meningkatkan daya ingat, penerapan, analisis, dan evaluasi.

2. Aspek afektif, pendidikan lingkungan hidup berfungsi meningkatkan penerimaan, penilaian, pengorganisasian dan karakteristik kepribadian dalam menata kehidupan dalam keselarasan dengan alam.

3. Aspek psikomotorik, pendidikan ling-kungan hidup berperan dalam meniru, memanipulasi dalam berinteraksi dengan lingkungan di sekitarnya dalam upaya meningkatkan budaya mencintai lingkungan.
4. Aspek minat, pendidikan lingkungan hidup berfungsi meningkatkan minat dalam diri anak.

\section{Rumusan Masalah}

Adapun yang menjadi permasalahan yang akan diteliti penulis adalah bagaimana perilaku warga sekolah (kepala sekolah, guru, siswa, petugas kebersihan sekolah) mengimplementasikan program Adiwiyata dalam pengelolaan lingkungan di SD Nahdlatul Ulama Medan.

\section{KAJIAN PUSTAKA}

Pengembangan Kebijakan Sekolah Peduli dan Berbudaya Lingkungan adalah untuk mewujudkan sekolah yang peduli dan berbudaya lingkungan maka diperlukan beberapa kebijakan sekolah yang mendukung dilaksanakannya kegiatan - kegiatan pendidikan lingkungan hidup oleh semua warga sekolah sesuai dengan prinsip-prinsip dasar Program Adiwiyata yaitu partisipatif dan berkelanjutan.

Pengembangan kebijakan sekolah tersebut antara lain:

1. Visi dan misi sekolah yang peduli dan berbudaya lingkungan. 
2. Kebijakan sekolah dalam mengembangkan

pembelajaran pendidikan lingkungan hidup.

3. Kebijakan peningkatan kapasitas sumber daya manusia (tenaga kependidikan dan non-kependidikan) di bidang pendidikan lingkungan hidup.

4. Kebijakan sekolah dalam upaya penghematan sumber daya alam.

5. Kebijakan sekolah yang mendukung terciptanya lingkungan sekolah yang bersih dan sehat.

6. Kebijakan sekolah untuk pengalokasian dan penggunaan dana bagi kegiatan yang terkait dengan masalah lingkungan hidup.

\section{Pengembangan Kurikulum \\ Berbasis Lingkungan}

Penyampaian materi lingkungan hidup kepada para siswa dapat dilakukan melalui kurikulum secara terintegrasi atau monolitik. Pengembangan materi, model pembelajaran dan metode belajar yang bervariasi, dilakukan untuk memberikan pemahaman kepada siswa tentang lingkungan hidup yang dikaitkan dengan persoalan lingkungan sehari-hari (isu local). Pengembangan kurikulum tersebut dapat dilakukan antara lain:

1. Pengembangan model pembelajaran lintas mata pelajaran.

2. Penggalian dan pengembangan materi dan persoalan lingkungan hidup yang ada di masyarakat sekitar.

3. Pengembangan metode belajar berbasis lingkungan dan budaya.

4. Pengembangan kegiatan kurikuler untuk meningkatkan pengetahuan dan kesadaran siswa tentang lingkungan hidup.

\section{Pengembangan}

Kegiatan

\section{Berbasis Partisipatif}

Untuk mewujudkan sekolah yang peduli dan berbudaya lingkungan, warga sekolah perlu dilibatkan dalam berbagai aktivitas pembelajaran lingkungan hidup. Selain itu sekolah juga diharapkan melibatkan masyarakat disekitarnya dalam melakukan berbagai kegiatan yang memberikan manfaat baik bagi warga sekolah, masyarakat maupun 
lingkungannya. Kegiatan-kegiatan tersebut antara lain:

1. Menciptakan kegiatan ekstra kurikuler-/kurikuler di bidang lingkungan hidup berbasis patisipatif di sekolah.

2. Mengikuti kegiatan aksi lingkungan hidup yang dilakukan oleh pihak luar.

3. Membangun kegiatan kemitraan atau memprakarsai pengembangan pendidikan lingkungan hidup di sekolah.

\section{Pengelolaan \\ dan \\ atau \\ Pengembangan Sarana \\ Pendukung Sekolah}

Dalam mewujudkan sekolah yang peduli dan berbudaya lingkungan perlu didukung sarana dan prasarana yang mencerminkan upaya pengelolaan lingkungan hidup, antara lain meliputi:

1. Pengembangan fungsi sarana pendukung sekolah yang ada untuk pendidikan lingkungan hidup.

2. Peningkatan kualitas pengelolaan lingkungan di dalam dan di luar kawasan sekolah.

3. Pengembangan sistem pengelolaan sampah.

\section{Tujuan Dan Manfaat}

Tujuan dari penelitian ini adalah : untuk mengkaji perilaku warga sekolah (kepala sekolah, guru, siswa, komite sekolah dan petugas kebersihan sekolah) mengimplementasikan program Adiwiyata dalam pengelolaan lingkungan di SD Nahdlatul Ulama Medan sehingga dinyatakan sebagai SD Adiwiyata Mandiri Sekolah Peduli dan Berbudaya Lingkungan (SPBL)

\section{Manfaat}

Terciptanya penyadaran warga sekolah, sehingga di kemudian hari warga sekolah tersebut Peduli dan Berbudaya Lingkungan dalam upaya-upaya penyelamatan lingkungan hidup dan pembangunan berkelanjutan.

\section{METODOLOGI}

Penelitian ini merupakan penelitian kualitatif yang bersifat deskriptif, karena Teknik pengumpulan data yang digunakan adalah wawancara dan observasi, selanjutnya pendokumentasian. Adapun teknik analisis data yang digunakan adalah model analisis deskriptif. Penelitian dilakukan di SD Nahdlatul Ulama Medan. dengan objek penelitian adalah efektivitas pelaksanaan program adiwiyata 
(sekolah peduli dan berbudaya lingkungan) bertujuan mencapai keberhasilan program Adiwiyata di sekolah SD Nahdlatul Ulama Medan.

\section{Lokasi Penelitian}

Penelitian dsikriptif ini mengambil tempat di SD Nahdlatul Ulama jalan Pukat No. 1, Kelurahan Bantam Timur, Kota Medan.

\section{HASIL PENELITIAN}

Sesuai dengan maksud dan tujuan yang akan dilakukan, pelaksanaan untuk mewujudkan sebagai Sekolah Adiwiyata, SD Nahdlatul Ulama Medan memiliki Visi dan Misi: visinya adalah menghasilkan insan cerdas yang berakhlak mulia dan berbudaya lingkungan. Sedangkan misinya adalah: 1) meningkatkan keterlaksanaan pendidikan karakter; 2) meningkatkan keterlaksanaan pendidikan lingkungan hidup; 3) meningkatkan keterlaksanaan pembelajaran bermutu. Ads 5 (lima) Tujuan Strategis dalam mencapai Visi dan Misi: 1) tersedia dan terjangkaunya layanan pendidikan berkarakter, 2) terjaminnya pendidikan lingkungan hidup, 3) tersedia dan terjangkaunya pembelajaran yang berkelanjutan, bermutu dan relevan dengan kebutuhan era global; 4) tersedianya sistem manajemen yang handal dalam menjamin terselenggaranya layanan pendidikan; 5) terjaminnya pendidikan ramah lingkungan.

\section{Pelaksanaan Penelitian}

Dari hasil diskusi dan wawancara terhadap lebih kurang 25 siswa peneliti melengkapai teoriteori terkait Adiwiyata jenis-jenis limbah dan pemanfaatan limbah dan daur ulang (Foto 7.1 dan Foto 7.2).

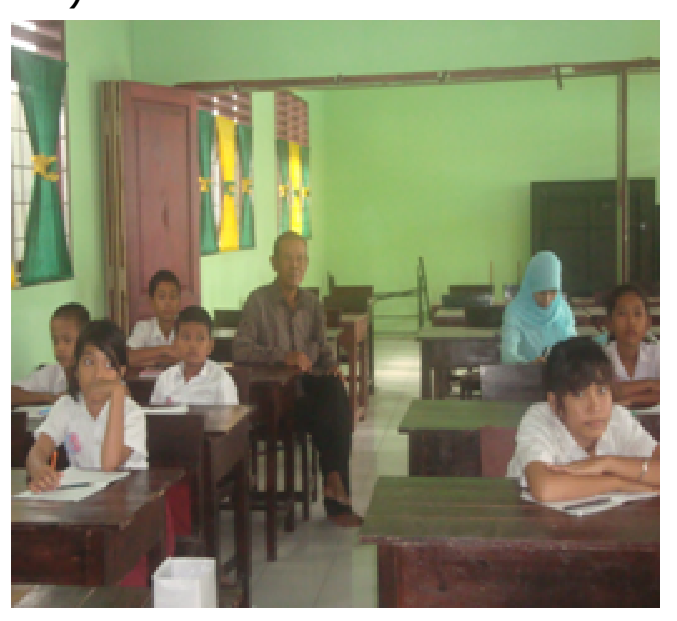

Foto 7.1. Pencerahan dan diskusi dengan Staf Pengajar dan siswa/i 


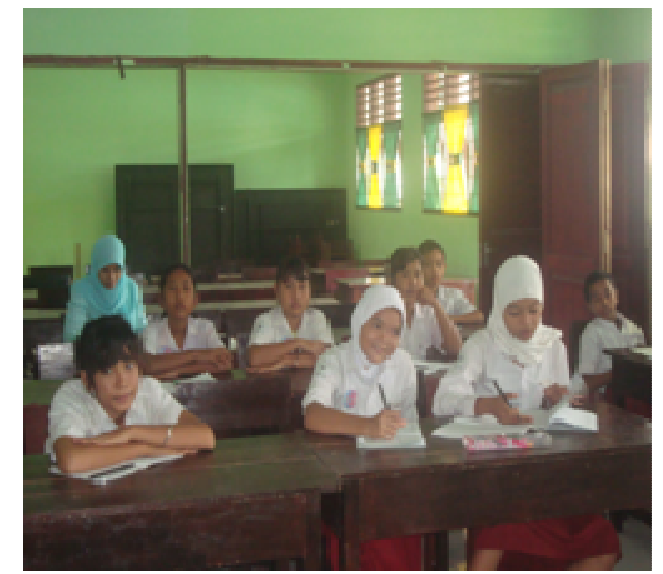

Foto 7.2. Bentu diskusi dan tanya jawab dengan Staf Pengajar dan siswa/i

Selama diskusi yang dilakukan dan tanya jawab dengan para pendidik menyangkut administrasi dan kurikulum tambahan terkait lingkungan, Sedangkan dengan para siswa menyangkut hasil karya pemanfaatan daur ulang limbah plastik, kertas dan pemanfaatan aqua bekas termasuk prakarya siswa ini merupakan salah satu syarat untuk menuju sekolah Adiwiyata (Foto 7.3 dan Foto 7.4).

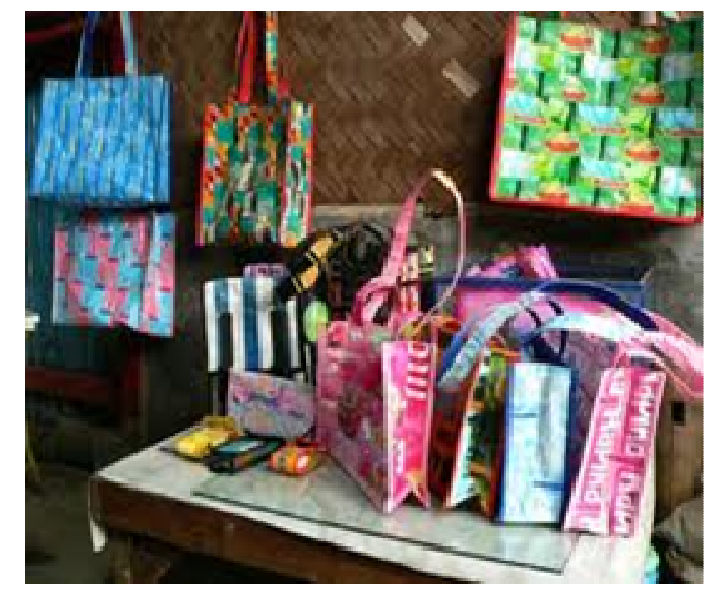

Foto 7.3. Daur limbah plastik karya guru dan anak didik.

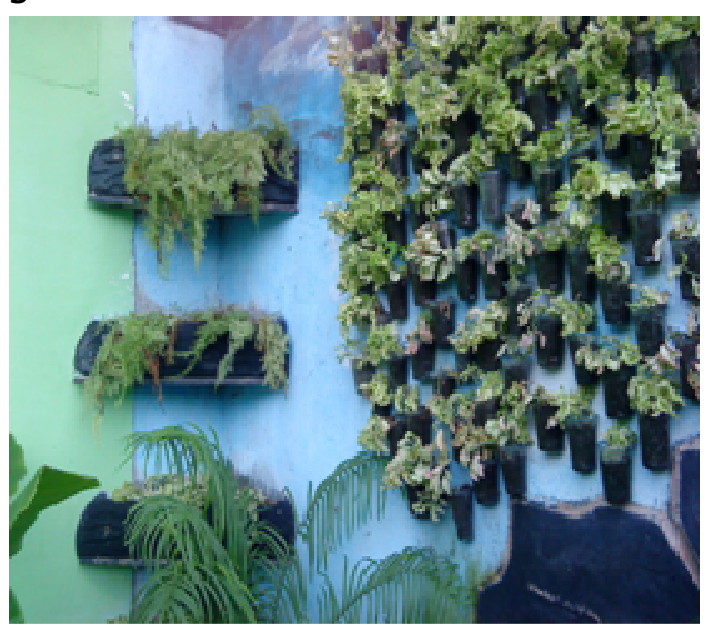

Foto 7.4. Hasil karya siswa/i me reuse limbah plastik 


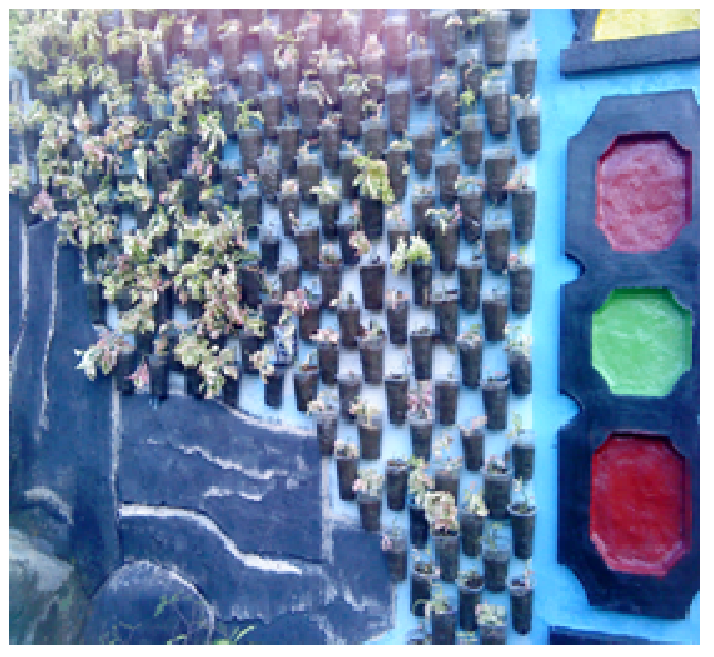

Foto 7.5. Hasil karya siswa/i dan staf pengajar limbah plastik Aqua

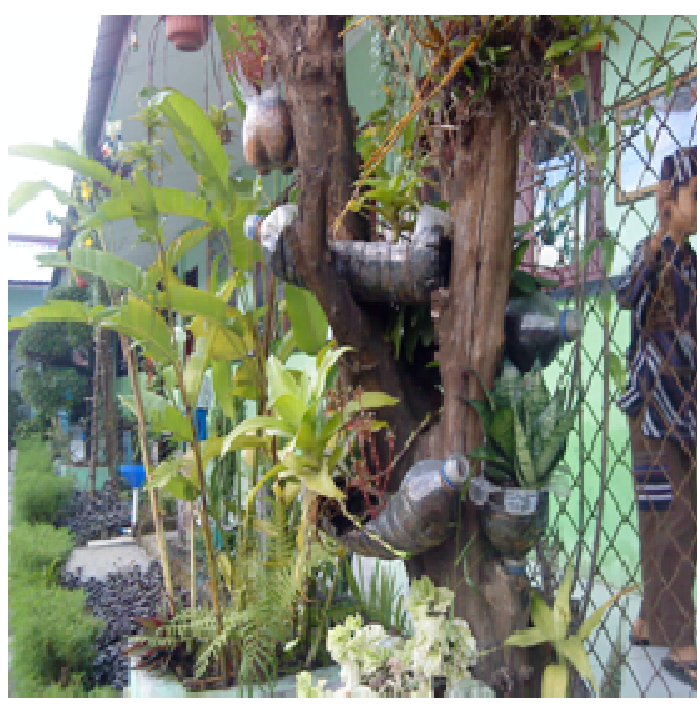

Foto 7.6. Limbah plastik botol Aquabermanfaat Sebagai pembibitan bunga lainnya..

Ruang dan kebersihan halaman sekitar sekolah serta pemanfaatan ruang untuk reklame/spanduk berupa informasi pesan-pesan lingkungan telah terlaksana dengan baik hal ini terlihat seperti pada (Foto 7.7). dan (Foto 7.8).

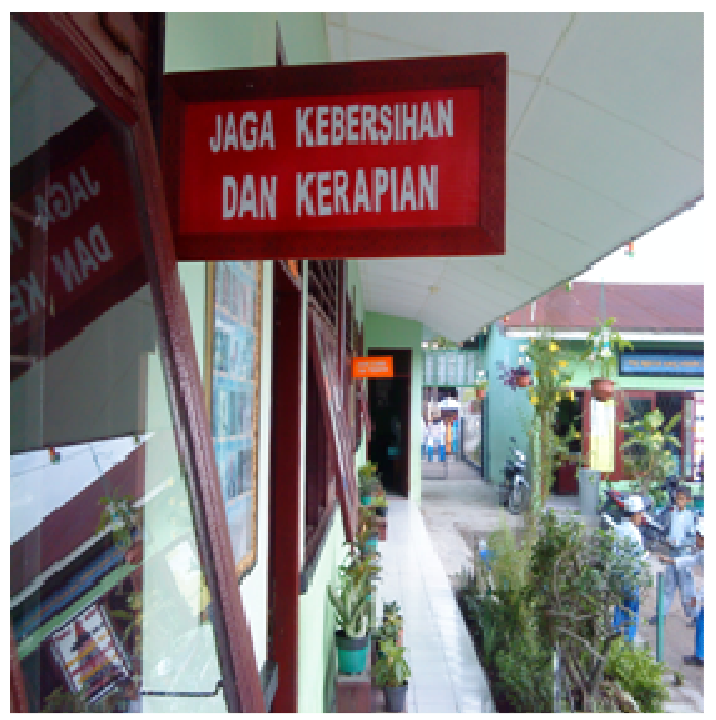

Foto 7.7. Bentuk kerjasama dengan instansis Pemerintah BLH Kota Meda,

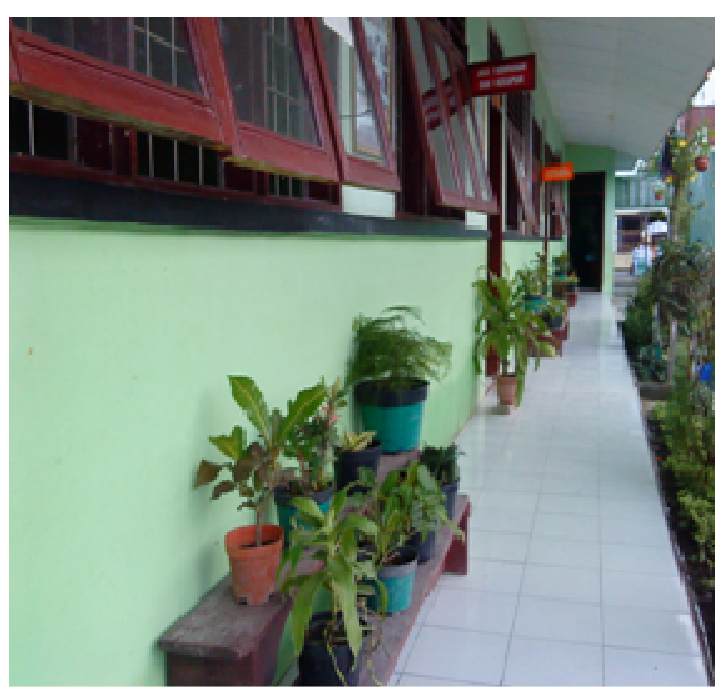

Foto 7.8. Bentuk kerjasama dengan instansi Pemerintah BLH Kota Meda, 
Dalam kegiatan partisipatif SD Nahdhatul Ulama Medan berkerjasama dengan Instansiinstansi pemerintah yaitu Badan Lingkungan Hidup Kota Medan dan Badan Lingkungan Hidup (BLH) Provinsi Sumatera Utara, Kecamatan Kelurahan dan Kepala Lingkungan setempat. Serta beberapa pengrajin tangan yang ada di kota Medan, para orang tuan dan LSM

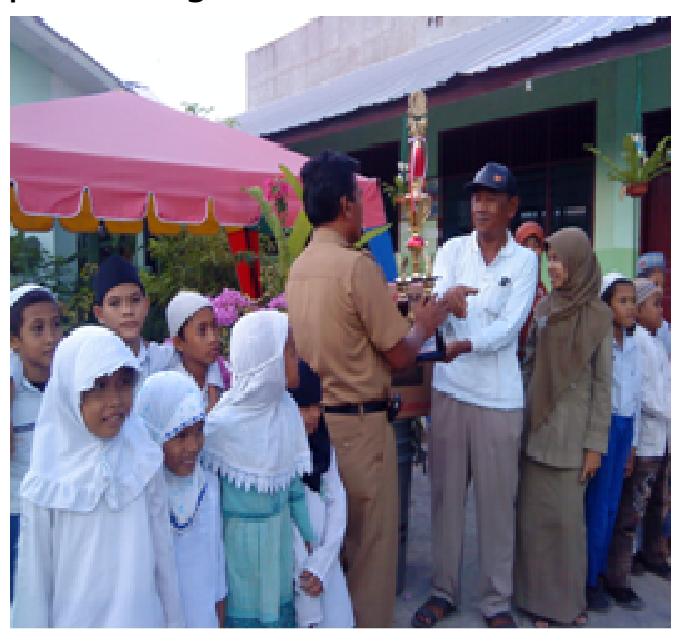

Foto 7.9. Bantuan dengan instansi Pemerintah BLH Kota Meda,

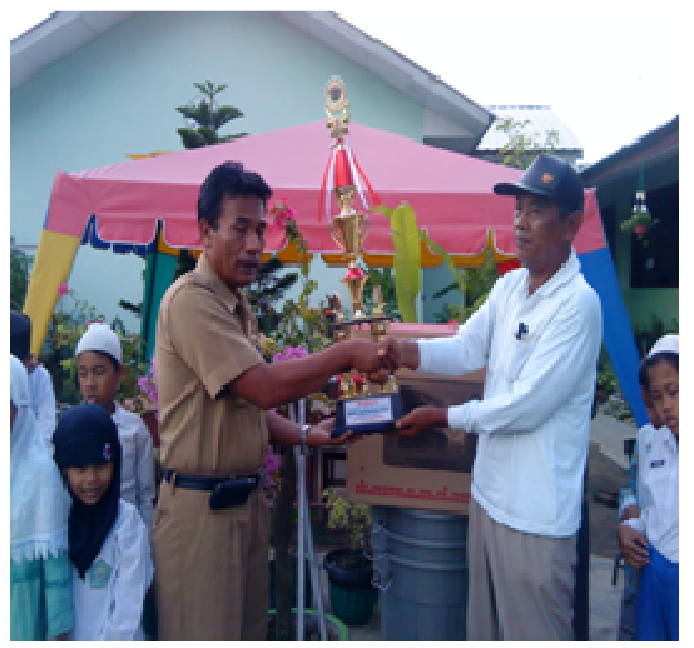

Foto 7.10.Bentuk bantuan dan piagam terbaik sekolah SBL tingkat SD oleh instansis Pemerintah BLH Kota Medan,

Hasil penilaian yang dilakukan oleh tim penilai dari instansi pemeirintah dan LSM yang telah dihunjuk, telah melakukan penilaian dan capaian sejauh mana Sekolah SD Nahdhatul Ulama mengimbaskan materi Adiwiyata terutama tertuang dalam visi dan misi sekolah tersebut. Selama penilaian yang dilaksanakan imbas menampilkan dan aksi lingkungan berupa produk-produk dari daur ulang, yang merupakan hasil karya siswa dan para pengejar dalam bentuk kurikulum, hasil karya, pemanfaatan limbah (daur ulang) dan menempatkan kurikulum lingkungan sampai ke penilaian pesan-pesan lingkungan.

Kepala sekolah Bapak Kusnadi serta bapak Hamzah Lubis Ketua Yayasan, sebagai penanggung jawab terlibat langsung dalam pengemebangan sekolah NU Peduli dan Berbuda Lingkungan terkait capaian Adiwiyata. Hal ini terbukti dengan mendapat peringkat sekolah Adiwyata tersebut di tingkat Nasional. 


\section{HAMBATAN DAN STRATEGI}

1. pendidikan lingkungan hidup selama ini, Pada SD Nhadlatul Ulama masih dijumpai berbagai situasi belum tersedianya petugas satuan tugas (Satgas).

2. SD Nhadlatul Ulama bagi siswa yang sekolah belum dikutip biaya sekolah dan sekarang masih didanai Yayasan dan beberapa sponsor yang "care" terhadap kemajuan pendidikan Sekolah Peduli dan Berbudaya Lingkungan (SPBL)

3. Tempat sampah masih terbatas serta didanai dari Pemkot atau Pemprov dan kadang-kadang dana juga berasal dari hasil menjual sampah atau botol.

4. Masyarakat kurang berperan dalam menerapkan pendidikan lingkungan hidup. Hambatan yang terjadi pada SD NU seperti kepsek antusias tetapi guru dan beberapa stafnya belum siap.

\section{Strategi}

Adapun srategi mengatasi hambatan perlu dilakukan langkahlangkah strategi yaitu: Kebijakan dari kepala sekolah untuk menerbitkan surat keputusan kepada guru, karyawan tentang uraian tugas serta tanggung jawab yang diterbitkan sebagai panduan pelaksanaan tugas, Lebif diintensifkan membangun komitmen dan membangun komunikasi antar siswa, keteladanan, memperbaiki kesalahan sehingga akan menentukan perilaku dalam bekerja seperti perilaku disiplin, penghematan sumber daya, kemudian dalam mengatasi kurangnya kesadaran lingkungan mayarakat sekitar, bahwa perlu mengundang beberapa elemen masyarakat. Pihak-pihak kepala lingkungan, Kelurahan perlu diintensifkan.

\section{KESIMPULAN}

Kesimpulan yang dapat ditulis dari penelitian ini adalah :

1. Implementasi Kebijakan Adiwiyata dilaksanakan berdasar Memorandum bersama antara Meneg dengan Mendiknas No 0142/U/1996 dan No. Kep 89/MenLH/5/1996, Kesepakatan Bersama KemenLH dengan Depdiknas KEP 7/MenLH/06/2005 dan No. 05/VI/KB/2005, UU No 20 Tahun 2003, UU RI No. 32 Tahun 2009 pada tingkat nasional kebijakan sekolah 
peduli dan berbudaya lingkungan.dan mengacu pada Visi dan misi sekolah ke arah peduli lingkungan dalam rangka mewujudkan warga sekolah yang bertanggung jawab dalam upaya perlindungan dan pengelolaan lingkungan hidup melalui tata kelola sekolah yang baik untuk mendukung pembangunan berkelanjutan.

2. Struktur kurikulum sudah memuat pengembangan diri terkait kebijakan perlindungan dan pengelolaan lingkungan hidup.

3. Telah dilaksanakan kerjasama dengan Instansi Pemko, Pemrov dan lembaga LSM, terkait Soaialisasi peraturan Adiwiyata dll.

\section{Saran}

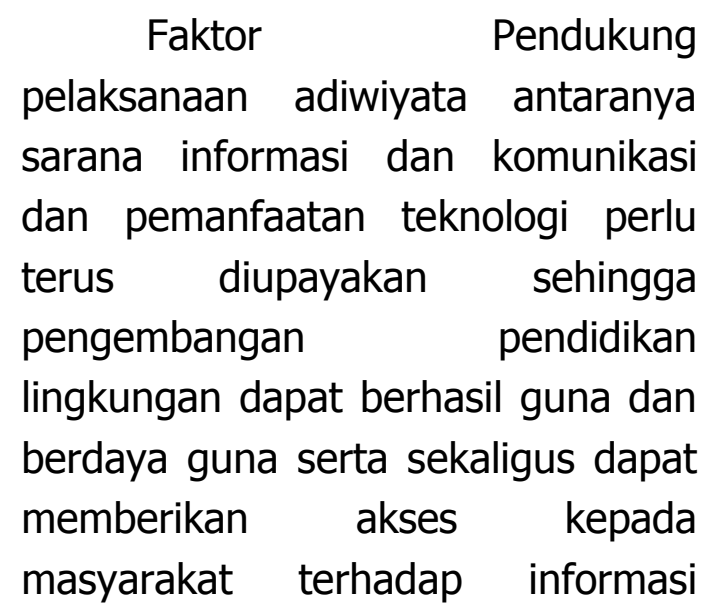

tentang Pendidikan Lingkungan Hidup.

\section{DAFTAR PUSTAKA}

Burhan Bungin. (2003). Metodologi Penelitian Kualitatif Aktualisasi Metodologis ke Arah Ragam Varian Kontemporer, Jakarta: PT RajaGrafindo Persada.

Kementerian Lingkungan Hidup. (2010). Pedoman Penggunaan Kriteria dan Standar untuk Aplikasi Daya Dukung dan Daya Tampung Lingkungan Hidup dalam Pengendalian Perkembangan Kawasan. KLH. Jakarta.

Miles, B.B., dan A.M. Huberman. (1992). Analisa Data Kualitatif. Jakarta: UI Press.

Nurjhani, M dan Widodo, A. (2009).

Penggunaan Multimedia Untuk Meningkatkan Penguasaan Konsep Mahasiswa dalam Perkuliahan "Konsep Dasar IPA", Prodi Pendidikan Guru Sekolah Dasar FIP: Tidak Diterbitkan.

Widaningsih. (2010). dikutip dari http://eprints. undip.ac.id/3146 3/1/bab1.pdf.online (Diunduh 22 Juli 2012). 